\title{
Anagnorisis (processing forgiveness): The mystical praxis-space of diaconal reaching out to the Other/others (the hopeful case of Joseph and his brothers)
}

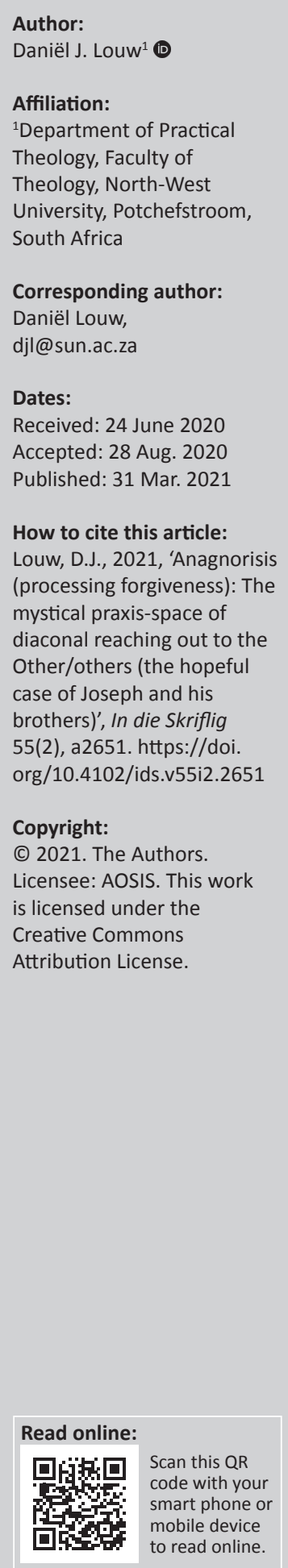

The following question is at stake: What entails forgiveness and reconciliation within processes of healing regarding schisms in a very diverse and polarised society? Despite the work of the Truth and Reconciliation Commission the burning question that still prevails: What is meant by a praxis of forgiveness and a spirituality of reconciliation within a post-apartheid dispensation? It is argued that forgiving and reconciling are not instant or merely 'handsome pardoning'. Both are embedded in processes of reaching out to the pain and hurt of the other. As a process, forgiveness starts with self-acknowledgement and should manifest in modes of compassionate being-with and diaconal acts of reaching out, creating spaces of 'mystical encounters'. In this regard, the notion of anagnorisis, as captured by narrating the encounter between Joseph and his brothers, should be read as an exemplification of reconciliation, directed by the missio Dei, promissio Dei and passio Dei. Within a Christian paradigm, Ernst Bloch's notion of docta spes, very aptly captures the core of pastoral, reconciliatory care: Hope care to the human soul (nēphēsh) - the search for life and meaning. 'Dum spiro - spero' [While I Breathe, I Hope].

Contribution: It is often the case that reconciliation is viewed as an instant event. The case of Joseph and his brothers illustrates the fact that reconciliation is in fact a mode of life, embedded over many years. In this way, reconciliation could be rendered as part of one's life story; as a mode of journeying through life, exemplifying the how of authentic human encounters. Reconciliation then becomes an ontic feature of relational integrity and indication of the quality of the human soul: Habitus as feeling from the hurt being of the other.

Keywords: forgiveness; reconciliation; anagnorisis; self-acknowledgment; narrative of Joseph and his brothers; process God; reconciling and forgiving as process categories.

\section{Introduction}

In her book Conversations with My Sons and Daughters, Mamphela (2012) wrote:

\begin{abstract}
Dialogues start with acknowledgement of the presence of others. The isiZulu greeting captures it best: 'Sazubona', Literally, 'we are seeing you'. Being seen and acknowledged is an affirmation of being connected with those around one and thereby be affirmed as part of the human family. Ubuntu is captured at that moment of recognition and being seen - that you are affirmed as a human being through recognition of your humanity by other human beings. (p. 183)
\end{abstract}

What is the impact of this remark on the current discourse on reconciling the many different diverse viewpoints and schismatic polarisations taking place within the social and political environment? What is meant by a Christian spirituality of a hope-giving source of forgiveness and reconciliation?

The South African society is torn apart by forms of 'new racism', 'social inequality', 'economic disparities' and a coronavirus disease 2019 (COVID-19) disruption of employment causing spiritual despair. The lockdown has resulted in nightmarish scenarios and a bleak future. The worst one is produced by the political opportunism of Julius Malema (2020):

If this white economy must collapse, let it collapse. If we are going to die of hunger, let us die with our boots on. It's not our economy. We must stay at home. If we are going to die because of hunger, let us die with our boots on. Let us die proud. (n.p.) 
How do we bridge and heal social schisms and ideological isolation or estrangement (Entfremdung)? What is the role of forgiveness in the healing of radical polarisation ${ }^{1}$ in the public domain? Can the reaching out to people in need be viewed as a mode (habitus) of forgiveness and act of reconciling opposing power struggles?

It seems that Archbishop Tutu's dream of a Rainbow Nation and President Cyril Ramaphosa's attempts ${ }^{2}$ to promote inclusive centralism (centripetal ${ }^{3}$ approach) are getting shipwrecked on the rocky coastline of relational and social resistance or ideological partitions (Mgxashe 2000):

The fallacy of the 'the rainbow nation' in South Africa today is loudly proclaimed by the huge gaps that will exist between the affluence of the average white person living in the suburbs and the poverty of Black South Africans living in the Townships. (p. 215)

And now, the burning question and theological challenge: If we can accept the fact that reconciliation and forgiveness are the keystones of Christian spirituality, how are we going to reach out to a new kind of racial backlash and inter-relational resistance - the unwillingness to accept unconditionally and to reach out to one another in the spirit of diaconal public engagements? Are forgiveness and reconciliatory attitudes merely mirages of Christian myths? But, from a Christian spiritual perspective, how should a praxis approach deal with the challenge to move from the quantification of forgiveness (success and results evolving around the question: How many times), to the qualification of forgiveness (disposition and exemplification in the how of being-with)?

If the notion of seventy times seven (Mt 18:22 - forgiving boundlessly) is symbolic for infinity, Christians are called to forgive an infinite number of times, because seventy times seven refers to a transcendent, mystical and divine space of a sustainable spirituality of forgiveness. Could the case of Joseph and his brothers serve as a directive for a diaconal praxis of reaching out to the other to overcome schismatic resistance? According to Luke 17:

If your brother sins, rebuke him, and if he repents, forgive him. If he sins against you seven times in a day, and seven times, come back to you and says, "I repent," forgive him. (vv. 3, 4)

1.Polarisation is, inter alia, a strategy of survival when one culture dominates, discriminates, ind humiliates another culture by means of the abuse of power 'Broederbond' Bond's primary motivation was to prevent the disappearance of the Afrikanervolk as a separate political, language, social and cultural entity. One of the instigating factors was the Anglo-Boer war with 26000 women and children dying in British concentrations camps (Serfontein1979:29). However, as Serfontein (1979:256) pointed out: On the left, polarisation already took place - the growing black conscious movement. According to Prof Gerrit Viljoen (in Serfontein 1979:256) polarisation broadens the question amongst white people: 'How do we maintain our identity and survive if we lose power?'

2.The theme of the State of the Nation Address (SONA) on 20 June 2019 was: 'Let's grow South Africa together as we celebrate 25 years of freedom.' An important undergirding theme was the notion of cooperation, working together, inclusiveness, sense of belongingness and the emphasis on 'for all South Africans'. 'Working together, we have laid a firm foundation on which we can build a country in which all may know peace and comfort and contentment' (Ramaphosa 2019).

3.A force that acts on a body or cohesive factor moving in a circular path and is directed towards the centre around which the body is moving; a centre that binds together and promotes an inclusive approach.
In terms of the narrative of Joseph, I want to add to the verbs rebuke, repent and forgive the notions reaching out, recognising or acknowledging, embracing (anagnorisis).

\section{The complexity of forgiveness as a paradigmatic framework for processes of reconciliation}

The basic intention of this article is to explore the following assumption and connect it to the hope-giving space of Christian spirituality and the hospitable charity of reaching out to the other or others. Forgiveness and reconciliation are networking, relational categories and evolved around processes of recognition, acknowledgement and processes of mutual encounters. Forgiveness is a process category and not an instant miracle that can wipe out the wrongdoings of the past. Forgiveness and reconciliation create spaces for humane encounters, addressing schismatic healing. They provide a spiritual and paradigmatic framework for a healing praxis of hope and honest acknowledgement (anagnorisis and self-discovery).

The complexity of a praxis of hope-giving is that forgiveness has to take the following problematic areas and questions into consideration.

\section{The interrelational space of interconnectivity and interdependent accountability}

It is the conviction of Henry Yazir (2000:168-169) that healing starts where space is created; where it is possible to face each other as human beings. One has to become engaged in processes by which human beings rediscover that humans are all interdependent; we can only exist through our common humanity (Yazir 2000:170). Yazir emphasises that healing, and therefore reconciliation presupposes accountability, acknowledgement and reparation. 'Only in this way can progress be made towards peaceful coexistence - as a basis for the promotion of a human rights culture' (Yazir 2000:172).

\section{Exoneration or forgiveness?}

Hargrave and Anderson (in Van Rhijn \& Meulink-Korf 2019:315) try to distinguish between exonerating and forgiving. Exonerating comprises two aspects, namely insight and understanding. Forgiving also comprises two aspects, namely giving the opportunity for compensation, and the overt act of forgiving. However, when forgiving it is extremely difficult to 'bury the hatchet', ${ }^{4}$ specifically when one has to deal with the pain of being hurt. The point is that it is extremely difficult to ask for forgiveness on a bended knee and not to reckon with the reality of the hurt (Hargrave in Van Rhijn \& Meulink-Korf 2019:317).

\footnotetext{
4.According to Hargrave (in Van Rhijn \& Meulink-Korf 2019), in an overt act of forgiving the victim and victimiser discuss the relational violation openly and come to an to an agre "The work of forgiveness, as outlined by Hargrave is defined as an effort in restoring love and trustworthiness to relationships, so that victins and victimisers can put a end to destructive entitlement. In forgiving, the victimised person is given reason to believe that the wrongdoer accepts responsibility for the injustice he or she caused and promises to act trustworthy in the future' (Hargrave in Van Rhijn \& Meulink-Kor 2019:316).
} 


\section{Cheap generosity? The quest for justice}

For the family therapist, Ivan Boszormenyi-Nagy (Van Rhijn \& Meulink-Korf 2019:317-318), the factor that needs to be addressed and abolished in processes of forgiving is cheap generosity as a superficial trait in forgiveness. For BoszormenyiNagy, exoneration is a process. The intention is that somebody is rendered the opportunity to make a new beginning in his or her relational reality. The appeal is on personal accountability within a desire for restoration of relational integrity. The focus is to start with a new beginning in the restoration of the justice of the human order' (Boszormenyi-Nagy in Van Rhijn \& Meulink-Korf 2019:321). According to Boszormenyi-Nagy, exoneration cannot be a process as in developmental psychology. One cannot split it into stages to be eventually managed. Process indicates a continuous engagement with the other, exemplifying justice and compassionate caregiving. What one should realise is that the criterion for valid and true exoneration is the principle of justice. Justice must be done, and one should take care that people are not subject to injustice (BoszormenyiNagy in Van Rhijn \& Meulink-Korf 2019:323).

\section{Repentance or remorse as a generator for forgiveness and authentic freedom?}

Against the background of the persecution of the Jews, and when Hitler was in charge for one year, Levinas wrote an article on how 'the Hitler-regime' was busy to rob European freedom by destroying time and blocking history (Van Rhijn \& Meulink-Korf 2019:324). Time became a condition of the irreparable (Levinas 1994). Since the wrongdoing, the past - in the mode of an accomplished fact (faits accomplis) weighs heavily on the future of humankind. The challenge now is the impossibility of the possible: to assemble freedom and time within the now. Levinas sees in Judaism a message of this possibility. Freedom is to wrestle with the wrongdoings of the past. The torment is an appeal on authentic remorse; it announces a kind of repentance that can serve as a generator for forgiveness; a repentance that can heal and repay, and restore authentic freedom (Le remords [...] annonce le repentir générateur du pardon qui répare) (Levinas 1994:29).

\section{Constituents of forgiveness and reconciliation}

With reference to the previous outline regarding the complexity of the interplay of forgiveness and reconciliation, one must accept the fact that both forgiveness and reconciliation are many layered concepts embedded in different religious, philosophical and cultural backgrounds. ${ }^{5}$ As a spiritual

5.The best example in literature on what is meant by forgiveness instead of revenge is described in the novel Les Miserable by Victor Hugo. The story revolves around the main characters: Jean Valjean and Colette - he, the forlorn child of the desperate, Fantine. When after being in prison for 19 years (for stealing a loaf of bread and for unsuccessful attempts at escape) the released convict, Jean Valjean, having been rejected by everyone else and taken in by the bishop of a small town, given a meal and a place to sleep, decides to leave in the middle of the night taking the bishop's silverware. When caught, the police bring him back to the bishop's residence, telling the bishop that Valjean had maintained that he had received the silver as a gift from the bishop that Valjean had maintained that he had received the silver as a gift from him. Jean Valjean, expecting the worst, hears to his amazement these words from the bishop: That is right. But my friend you left so early/Surely something slipped your mind/[giving him two silver candlesticks]/You forgot I gave these also/Would you leave the best behind?' Then as the police release him the bishop adds, 'But remember this, my brother/See in this some higher plan/You must use this precious silver/To become an honest man/By the witness of the martyrs/By the Passion and the Blood/God has raised you out of darkness/I have bought your soul for God! (Louw 2016:546 footnote 23). category in the Christian faith tradition, forgiveness is a category sui generis. However, it cannot be isolated from other categories. Thus, the emphasis on the following constituents of forgiveness and reconciliation:

Accountability and responsibility: Accountability is not about punishment. Accountability describes a wide variety of mechanisms for identifying individual and group responsibility. To hold someone to account is to identify an individual's responsibility for an act and to impose some cost or benefit upon that individual as a sign of approval or disapproval (Slye 2000:178).

Remembering, narrating and recognition: Forgiveness is not about an attempt to forget, but to remember the wrongdoings of the past through the eyes of the sufferers and victims. The simple truth is that: 'By remembering and telling, we ... prevent forgetfulness from killing the victims twice' (Verwoerd 2000:159). Remembering is, according to Paul Ricoeur (in Verwoerd 2000:163), a moral duty; we owe a debt to the victims. Memory and narration can set one free.

Acknowledgement within a public space of mutual encountering: Forgiveness operates within the interplay between victim and perpetrator. Both need to become 'a face' for one another; encounters imply countenance. Judge Goldstone (2000:x) pointed out the necessity of public spaces wherein acknowledgements can take place: 'I have witnessed time and again in South Africa, Bosnia and Rwanda the importance of that acknowledgement to victims. It is frequently the beginning of their healing process'.

The ethics and moral framework of imposing justice (restorative justice): Forgiveness and reconciliation cannot be founded on the instability of emotional catharsis. Both function within the confines of ethical directives and moral frameworks to foster human rights and safeguard human dignity. In this regard, Esterhuyse (2000:150) referred to the need for transformational justice. Reconciliation should lead to a culture of trust and freedom. It should be directed by structural and other reparations and adjustments. 'Put differently, reconciliation must become flesh and blood through concrete deeds, through making sacrifices, through transformation. Reconciliation can, therefore, never be a cheap word' (Esterhuyse 2000:154).

A process of connecting with others: Re-connectivity, co-humanity and new modes of 'peaceful coexistence' (Villa-Vicencio 2000:207-208): Forgiveness and reconciliation cannot be enforced and demanded. It presupposes choices, informed decision-making, insight, responsibility within the relational dynamics of what one can call 'timing'. It is embedded in happenstances and events; it presupposes appropriate timing and cannot be forecasted. Therefore, the process character of both: 'Wait until ...': In fact, the process of reconciliation - and it is a process not a once-off event or happening - is part of a much deeper and larger process: the process of transformation (Esterhuyse 2000:145). 
Necessity of a judicial framework: The previous mentioned constituents of forgiveness and reconciliation are framed within a very specific paradigmatic framework that can be called a legal framework, namely Constitutional democracy (Villa-Vicencio \& Verwoerd 2000:xv). As a result of the necessity for a more judicial and legal framework for processes of forgiving and reconciling, the Truth and Reconciliation Commission of South Africa was established in 1995. Their work should be assessed against this background (Meiring 1999:13). The first rule of the constitution refers to the following basic value undergirding all clauses: 'Human dignity, the achievement of equality and the advancement of human rights and freedoms' (Constitution of the Republic of South Africa 1996:1).

The constitutional framework is indeed fundamental to implementing forgiveness and reconciliation. But do we need more than a constitutional framework?

\section{The need for a spiritual framework?}

It will further be argued that a constitutional framework should be supplemented by a spiritual framework, that is, a framework that defines habitus, disposition, intention and purposefulness of life in order to safeguard sustainability, meaningful change and hopeful encouragement (never to give up). Thus, the emphasis on the spiritual framework of 'covenantal compassion' within the intimate space of koinonia [sense of belongingness - the public space of the fellowship of believers] and diaconal reaching out to the vulnerable other (praxis of sharing and hospitable engagement).

Creating a space for forgiveness and reconciliation are not about merely exoneration (to be excused and pardoned for transgressions and wrongdoings). It is not about 'handsome apology' (Tutu in Du Preez 2013:18), ${ }^{6}$ but within a Christian theological paradigm, fundamentally about spiritual directing. It is about an ontic stance of being liberated to because of expiation and sacrifice founded by the pity, mercy and grace of God, exemplified in the theologia crucis [theology of the cross] (Louw 2016). ${ }^{7}$

The basic assumption is that the appropriateness of forgiveness is not assessed by the impact of the outcome (effectivity and

6. But we should acknowledge the hurt and damage it caused, and the direct and indirect ways we benefited from white domination; we should acknowledge that the legacy of apartheid still affects our communities; we should communicate that to people who were so hurt and damaged; and we should take responsibility for our past and that of our ancestors' (Du Preez 2013:23-24).

7.It should be noted that whilst forgiveness is about the dimension of unconditional exoneration and negation or annulment, reconciliation focuses on the establishment of harmony or balance, equity, justice, fairness, peace, reorientation, constructive engagements, gestures of forgiveness and renewal of relationships, that is, formation of new bonds of trust, coexistence, co-humanity and humane cooperation. The distinction between forgiveness and reconciliation is not about total differentiation. Within a Christian spiritual perspective, they are two sides of the same coin, namely acts of grace, unconditional love, sacrificial ethics and covenantal faithfulness. The point is, both forgiveness and reconciliation cannot be separated from justice, fairness and acts of retribution, compensation and indemnification. Another complicating factor is that of remembrance and how to go about with painful memories regarding the past that cannot be deleted, ignored or about with painful memories regarding the past that cannot be deleted, ignored or forgotten. The interplay between forgiveness (annihilation), reconciliation (restitution and to become reconnected again) and the ethics of justice and fairnes is indeed complex. However, what is quite clear is that forgiveness and reconciliation cannot be managed with merely managerial and communication skills. It is never instant and immediate so that everything is set right in one moment. Both forgiveness and reconciliation are embedded in the dynamics of relational networking and presuppose a process approach. quantification), but by the intention (spirituality of habitus qualitative approach). ${ }^{8}$ On a volitional level, diaconal acts (practical engagements) should exemplify a praxis of anagnorisis as a container of the theological, steering factor of a covenantal truth: I am who I am (divine promissio). The processing events of an engaging Exodus-God (compassionate being-with) align processes of reconciling forgiveness. Forgiveness in social contexts is embedded in mutual encounters in which the perpetrator is forgiven by the victim and the victim forgiven by the perpetrator - thus, the case of Joseph and his brothers (Thomas Mann 1970).

\section{Directives for a praxis of reaching out}

The exposition of what forgiving and reconciling as spiritual categories entail, will be developed along the following directives for a praxis of reaching out:

- the yearning of healing spaces: mystical desire (désir métaphysique) (Levinas 1994) (The portrait of an 'I' without an 'other' [l'autre])

- the soulful, habitual change and movement of wounded healers: From hostility to hospitality (Henry Nouwen 1979)

- the painful process: From self-discovery (identity) to compassionate being-with/embracement - the praxis of a loving gaze (Joseph and his brothers - Thomas Mann 1970).

\section{The yearning of healing spaces: Mystical desire (désir métaphysique)}

In terms of Emmanuel Levinas, a public meeting space is defined by the presence of the Other or other. This space is essentially metaphysical and encompassed by 'transcendence'. Levinas sometimes writes 'the other' (l'autre) with a capital: Other (L'autre). In other cases, he uses only 'other' (without the capital). The implication is that even Other (L'autre) can be translated as 'the other' or an 'other'. Sometimes, he even uses the older form of 'others' (autrui). 'Others' then means, specifically, the other human being (the other person), or fellow human being. (Van Rhijn \& Meulink-Korf 2019:100-130). The other as fellow human being is in fact not our opponent but our guest (the metaphysical other): Inviting us into the humane space of getting befriended, saving us from becoming destructive wild animals. ${ }^{9}$

The further implication is that place and space is not a flat horizontal line open to merely empirical observation but a 'vast realm of transcendence' (welkin and firmament). The whole

8.In order to rediscover the power of forgiveness as a feature of a spiritual praxis of reconnecting to the other, this article will explore basic praxis directives of a 'processing forgiveness', derived from narratives of Anagnorisis: The healing power of 'mutual acknowledgement'. The further presupposition is that praxis is not merely about practical skill and statistics of empirical data. Praxis refers to the driving and steering force in acts and practical engagements on the level of volitional commitments to a theology of anagnorisis, that is, to the conative factor exemplified in the act, and the idea about a 'substitutional truth' and expiatory acknowledgement.

9.This perspective is underlined by Rudger Bregman's thought-provoking book Humankind: A Hopeful History (2020). Rather than a pessimistic or optimistic view on humankind, Bregman's view is about a realistic aesthetics: 'In reality, argues Bregman, when cities are subject to bombing campaigns or when a group of boys is Bregman, when cities are subject to bombing campaigns or when a group of boys is
shipwrecked on a remote island, what's notable is the degree of cooperation and shipwrecked on a remote island, what's notable is the degr
communal spirit that comes to the fore' (Andrew 2020). 
notion of 'transcendent' has many layers of meaning (Levinas 1978:192-207). In the first place, 'transcendent' refers to a relation with an end term (an ultimate entity) that cannot be reduced to the inner dynamics - the playful dynamics of interiority (jeu intérieur). Transcendent does not refer to the inner realm of human mindfulness. Furthermore, it cannot be reduced to any kind of representation within the realm of observational facticity. The metaphysical movement represents a yearning, longing and desire for something invisible. In other words, it is about a yearning and urge that are not the result of a mere theory, thesis or hypothesis. It is also not a mere regressive longing for a birthplace or fatherland. It is about a metaphysical desire for 'invisibility'. The yearning for something invisible describes a metaphysical movement towards what is indeed transcendent and outside the grasp of mere intellectuality: the yearning for the befriended the Other/others.

The transcendent as longing is an inadequacy (the insufficient ability of reason), and thus essentially, and necessarily a transcendence (désir métafysique) (Van Rhijn \& Meulink-Korf 2019). The existential unrest, the fact that I am addressed by the visage of the other and challenged not to present carelessness, creates a humane condition (condition humaine) par excellence. The deficiency of being is about being addressed and directed by the relation with the other. It constitutes the alterity of being (metaphysical relationship). The suffocating human being then finds an external point of justice that safeguards human dignity, a non-judgemental space of 'home' - the intimacy of grace and unconditional love, a space for forgiveness and reconciliation, re-connectedness in the sense of belongingness. In terms of Levinas, fellowship, intimacy and a sense of belongingness (koinonia) are pointers for becoming aware of a metaphysical trace - the peculiar trace of the Other. The challenge is not to try and track the footprints, because, in themselves, they are not signs. One should rather reach out to all the others that reside in the footprint of 'illeity' (phenomenology of impersonal being a sign or trace in the empirical sphere that refers to transcendence: He is there) (Levinas 1990:99).

Forgiveness and reconciliation cannot be captured by statistics and empirical data alone. It needs a space in which all human beings are perceived as representatives of the Other or other. Both needs an acute awareness of a divine presence: God's being there (Coram Deo) within the suffering of human beings; the presence ${ }^{10}$ of God whilst meeting the other or others and reaching out to their predicament of suffering and exposure to different kinds of public and social injustice. 'In a spiritual sense, the sacrality of our journey is made more evident by the manifestation of the Divine Presence "in whom we live, and move, and have our being"'(Ac. 17:28; Hernandez 2012:1). Thus being-there for the other or others in creating a transcendent space of divine grace, presupposes a very specific disposition in compassionate caregiving: the openness and unconditionality of hospitality.

10.Sensing the presence of God in time and space.

\section{The soulful, habitual change and movement of wounded healers: From hostile prejudice to hospital servitude (Henry Nouwen)}

As said, forgiveness and acts of reconciliatory outreach are embedded in the dynamics of relational networking. The complexity of both demand a very specific habitus that implies more than merely a sympathetic mode of understanding. To really care and to become involved, requires servitude and, what Henry Nouwen called, 'On becoming a wounded healer' (Louw 2016:283).

With the notion of becoming a 'wounded healer', Henri Nouwen draws attention to pastors' weakness and brokenness. Especially in our modern world, they experience intense alienation and loneliness. This loneliness is often the worst component of their woundedness. They must care for lonely people whilst being intensely aware of their own weakness and many culturally inflicted discriminatory prejudices. 'He is called to be the wounded healer, the one who must look after his own wounds but at the same time be prepared to heal the wounds of others' (Nouwen 1979:82).

The notion of a wounded healer within a Christian paradigm refers to the servant metaphor in pastoral caregiving, that is, unconditional identification with the predicament of suffering (pathos [woundedness] and therapon as a mode of beingthere and being-with). The servant-metaphor in Scripture communicates the identification of God with human suffering in a very special sense. The servant-metaphor uniquely links God's compassion to human suffering because of sin, illness, persecution, disruption and death. It indicates God's pathos and compassion for our human needs (Louw 2016:281-283).

The metaphor ebed Jahwe (Greek: pais Theou) figures strongly in Isaiah's prophesy. ${ }^{11}$ God's identification with human suffering clearly comes to the fore in Jesus Christ's work. He is God's doulos par excellence (Mt 12:18; Ac 4:27). In Luke 22:37, Jesus applies the 'suffering servant' dictum of Isaiah 53 to himself. Applied to pastoral care, this means that the servant metaphor conveys the idea of sacrifice and identification with suffering human beings in need. Pastoral care is not a replacement of Christ's sacrifice, but communicates Christ's vicarious suffering with the view to healing and acts of reconciling. Therefore, the Septuagint (LXX) often does not translate slave into doulos, but into therapon. In the New Testament, the verb therapeuo mainly indicates comprehensive healing (Graber \& Müller 1978:164) creating space for people to become whole again (Louw 2016). This space coincides with what Emmanuel Levinas (1990) has called désir métafysique.

11. Without a further discussion of the question whether the Lord's suffering servant was Isaiah himself or another historical or messianic figure, the important meaning was Isaiah himself or another historical or messianic figure, the important meaning of this metaphor is the following (Louw 2016:281): (1) In the image of a servant, the Servant announces God's will (Is 42:3) and he himself confirms his faithfu covenantal care (Is 42:6); (2) the servant confirms God's sovereignty and the maintenance of justice (Is 49:1-6); (3) the servant confirms the motif of comfort, sustenance and support (Is 50:4-9); (4) in the Servant's suffering, he acts vicariously and is punished and abused on behalf of others (Is 52:13-53:12) in order to exemplify the significance of both forgiveness and reconciliation. 
Hospitality and how one deals with the stranger or outsider could be viewed as one of the cornerstones of a praxis of reconciliatory love and hope in the Old Testament. The basis for hospitality is the conviction in Israel that the encounter between God and his people is based on the principle of God's hospitality (Vosloo 2006:64). It is closely connected to what Fitchett and Grossoehme (2012:388) called the tenet of tikkun odam [to repair the world] in Judaism. 'Efforts to repair the world are mitzvot (acts of human kindness rooted in commandments' (Fitchett \& Grossoehme 2012:388).

In his book, Reaching out Henry Nouwen (1998) identified the shift from hostility to hospitality as one of the most important shifts or movements of the human soul in order to foster spiritual growth. Hospitality exceeds the threat of xenophobia [the fear of strangers] and racial or cultural discrimination; it points to xenophilia.

One of the most profound illustrations of xenophilia as an exemplification of a habitus of becoming a wounded healer and creating a metaphysical space of reconciliatory healing, is captured in the narrative of Joseph and his brothers in the Old Testament (Gn 37-50), culminating in the very moving scene where Joseph revealed himself to his brother and embraced them as a token of true forgiveness and profound reconciliation. Genesis 45:3: 'Joseph said to his brothers, "I am Joseph!"'. The brothers responded with terrific dread and anxiety, overwhelmed by anguish mixed with guilt. And then the climax in Genesis 45:

Then he threw his arms around his brother Benjamin and wept. and Benjamin embraced him, weeping. And he kissed all his brothers and wept over them. Afterwards his brothers talked with him. (vv. 14-15)

\section{The painful process: From self- discovery (identity) to compassionate being-with or embracement - The praxis of a loving gaze (Joseph and his brothers - Thomas Mann 1970)}

The acknowledgement (I am Joseph - the supposed victim); the distressed brothers (the so-called perpetrators); the weeping and embracement (exemplification of reconciliatory forgiveness) and the talking of the brothers (the articulation of all the happenstances by means of dialogue) convey, to my mind, what forgiveness and reconciliation as process categories entail within a concrete praxis of compassionate reaching out.

Ernst Bloch (1969) called this moment of reaching out and embracement between Joseph and his brothers an exemplification of the principle of hope (docta spes) (Louw 2016:403). The act is twofold: (1) to create a wisdom that will imply a praxis-engagement (even a revolutionary engagement of radical transformation) in all forms of human estrangement in order to create a horizon of meaning (Heimat) - the 'where to' of purposeful hoping, (2) an ethics and aesthetics of human liberation, which implies 'Glück' [fulfilment as existential happiness] (Bloch 1969:401). The latter should not be interpreted in terms of success in affluent societies, or the prestige of achievement ethics, but as the aha-event when human beings discover their identity and dignity. This event of discovering a human space for living and mutual acknowledgement is what Bloch calls anagnorisis (Louw 2016:403).

The healing of caring and hoping is, for Bloch captured by the notion of anagnoris (the discovery of true identity and the humanum - human liberation, freedom and dignity beyond any form of inhumane oppression) as illustrated in the meeting between Joseph and his brothers in Egypt after their betrayal. It is within this space of embracement, beyond the option of revenge, that human identity is affirmed, confirmed, established and true reconciliation as sign of absolute and legitimate, authentic forgiveness takes place. The latter can only be realised when human beings re-unite beyond their differences and quarrels and meet one another within the realm of Heimat: the embracement of unconditional love human fulfilment (Bloch 1959:238); authentic self-encounter (anagnorisis). ${ }^{12}$

In the act of embracement, Joseph exchanged the paradigm of hateful revenge for a paradigm of amazing grace. A sense of belongingness and the comfort of forgiveness created a space for experiencing human dignity. Without a space and place for true embracement, human dignity and the notions of forgiveness and reconciliation, remain formal principles. In anagnorisis, human dignity becomes an existential reality, as it is embodied in the hospitality of grace.

Anagnorisis stems from the Greek verb anaginōskō [to know exactly, or to know again, acknowledge] (Blunk 1975:245). Anagnōsis occasionally meant recognising, but also referred to reading aloud, especially in meetings of the court. It was used in, for example, cultic readings. The cultic reading aloud of the divine commandments and legal requirements was an early practice at the great Israelite festivals (Ex 34:7; cf. Jos. 24:25; Blunk 1975:245). What Joseph did actually was to demonstrate a lectionary of the Torah. The palace of Pharaoh was transformed into a temple of Yahweh; the secular space became a holy place; an acknowledgement of a sacrament of human dignity.

\section{The mystery of 'presentness' (Thomas Mann)}

Thomas Mann $(1970: 32,33)$ started his novel on the encounter between Joseph and his brothers as an exemplification of the

12.Anagnorisis differs from psychoanalysis and the notion of self-maintenance (Louw 2016:404-405). In this respect, Bloch (1962:351) criticises Freud and Jung. Freud, with the notion of libido, encapsulates the self in terms of the prison of the past. Dreams and expectations stem from suppressions of the past. Instead of progression and hope, a human being becomes a captive of processes of resignation and regression. The libido can produce nothing new. Freud and Jun promite regression rather than progression. Instead of libido, Bloch (1959:71) promote reg (1959:71) posed the notion of a utopian hunger or urge, or longing for future identity (Heimat) (Levins 19g4: desir metafysique). Instead of psychoanalysis, anagnorisis (the encount a weidentity of human embracement) anticipates a sum bonum or ultimate reality Ultimum) (Bloch 1968:271). The ultimate of life is captured by the notion of nurture and compassionate care: die Sorge (Bloch 1968:249). 
truth of reconciliation and forgiveness with two remarks on the significance of processing forgiveness by referring to: (1) the importance of a timing presence in the present: 'the essence of life is presentness' and (2) the art of narrating life events within the awareness of life's mystery: 'Feast of storytelling, thou art the festal garment of life's mystery'.

For Mann, biblical narratives are encircled by the Godimage of a 'processing God'. God is focused on a significant future '... in whose will inscrutable, great, far reaching things were in process of becoming'. The implication for understanding God is that he himself is also in the process of becoming (Mann 1970):

... and thus was a God of unrest, a God of cares, who must be sought for, for whom one must at all times keep oneself free, mobile and in readiness. (p. 31)

The whole story of Joseph and his disposition of anagnorisis, hope-giving and reconciliatory embracement of the so-called 11 perpetrators, exemplified this processing God of unrest and care.

The painting in Figure 1 reflects on both the vanity of Joseph with his 'Amazing Technicolour Dream Coat' (his brothers and the stars, moon and sun bowing before Joseph), and his embracing and reconciling outreach to his brothers within the bright light of God's pity and grace (Mann 1970):

And Joseph? He had got up from his seat and glittering tears ran down his cheeks. For it happened that the shaft of light which

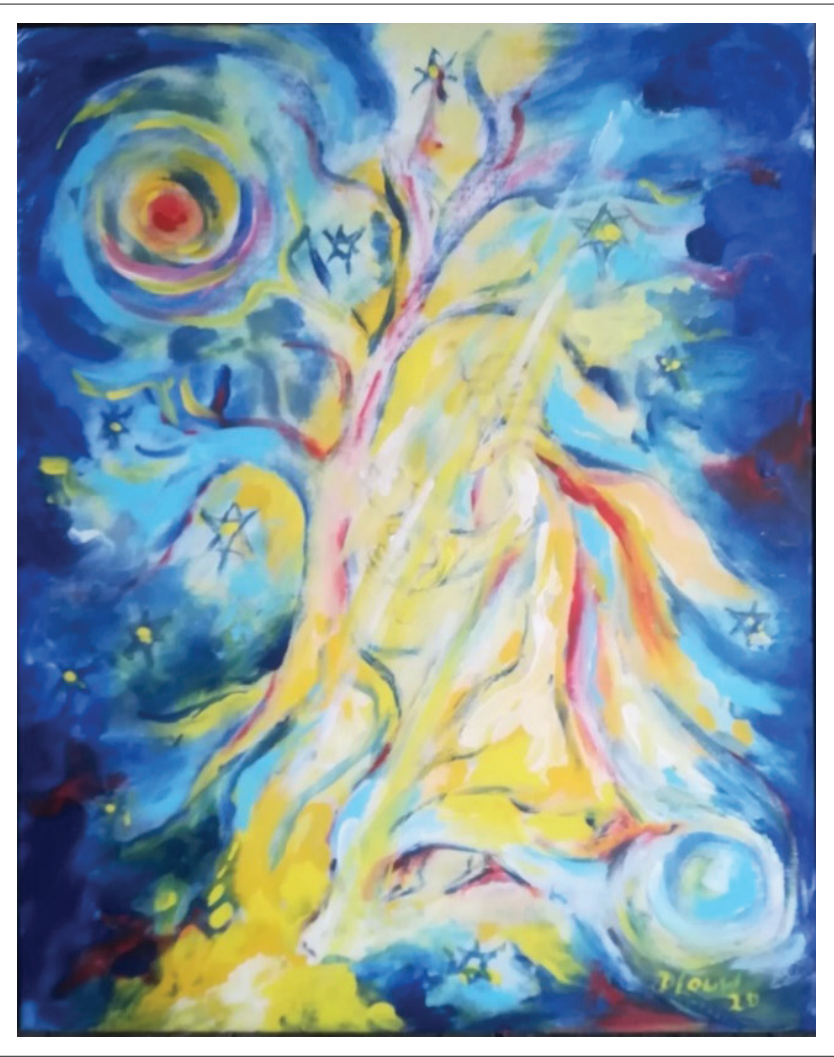

Source: Painting by, and published with permission from the author, Daniël J. Louw. FIGURE 1: Joseph and his Amazing Technicolour Dream-coat. had been falling aslant upon the group of brothers had now moved round and was coming through an opening at the end of the hall. It fell directly on Joseph's face and in it his tears glittered like jewels. (p. 1114)

In this story about forgiveness and reconciliation as process, the first hallmark for authenticity and legitimacy is acknowledgement as self-discovery - the 'presumption' of identity and taking oneself seriously. 'He who does not take himself seriously is soon lost' (Mann 1970:1139). To recognise oneself is a form of piety, that is, to discover one's own dignity and identity as an assimilation 'into the eternalness of being' (Mann 1970:1139). In selfacknowledgement, the complexity of the interplay between perpetrator and victim in the display of processing forgiveness, plays a decisive role. Compassion and pity prepared Joseph not for pointing in the first place to his brothers as the guilty perpetrators, but to discover himself as the victim: 'I am in fact the perpetrator myself.' So, the first acknowledgment for Joseph to discover was what Mann (1970:1051) called 'the peacock in himself': 'What a young peacock I was in those days, a regular young cock of the walk, full of really vicious vanity and self-importance!'. Therefore, after the death of Jacob, the brothers feared that Joseph will now take revenge. Thus, the reason why Benjamin delivered his plea that Joseph must forgive them their trespasses and not repay them. But very surprisingly, Joseph, the victim, turns to himself and shifted his position from the suffering victim to the position of self-acknowledgement: 'I betrayed my brother; I am also a perpetrator.' He (Mann 1970) thus professed:

But if it is a question of pardon between us human beings, then it is I myself must beg for it, for you had perforce to be cast in the villain's part so that things might turn out as they did. (p. 1207)

And this is the mystery, but also pious wisdom of processing forgiveness and presencing reconciliation: It turns around the complexity of the interplay perpetrator the victim as a mutual form of self-acknowledgement. In order to forgive, one has to forgive himself or herself first. The victim also becomes the perpetrator; the perpetrator felt the hurt and pain of the victim and turned into victim. ${ }^{13}$ Reconciliation demands exchange of places and acts of substitution.

The whole of the New Testament is actually about the embracement of unconditional love and the acknowledgement by amazing, substitutionary grace. In John 15:15, Jesus made a profound statement: 'I have called you friends' (Louw 2016:436-437). Our position before God shifted from the discrimination position of a slave into the inclusive and equal position of a friend. In the 'covenant business', God and human beings become partners for life. Jesus exemplified

13.In this regard, René Girard's mimetic theory is quite informative. Within the perpetrator-victim polarisation, the victim tends to put all the blame on the perpetrator perpetrator, accepting a kind of passive self-pity. His mimetic theory impels victims to move from a passive kind of masochistic helplessness (the innocent victim) purpont and purpose driven praxis orientation. For that reason, the solidarity that a liberating stance asks from those who partake in it, is to the point of darse a si mismo [give oneself to something] (Girard 1986). 
anagnorisis: 'Greater love has no one than this, that he lay down his life for his friends' (Jn 15:13). Anagnorisis is about the aesthetics, ethos and habitus of unconditional love. Ethos therefore should determine ethics: 'My command is this: Love each other as I have loved you' (Jn 15:12; Louw 2016:437).

\section{Conclusion}

The practice of forgiveness does not consist of trying to forget, exonerate or liberate somebody on parole (probation). The practice of forgiveness means accepting God's unconditional grace through faith and setting the other free; handing the other over to the grace of God (Louw 2016:545). 'Forgiveness' is a lifegiving event and new state of being. Hope for reconciliation is not based on emotional wishful thinking. Hope is a new state of being and a new state of mind - a condition and source of reconciliatory forgiveness (see Figure 2):

- True forgiveness is a conscious process that involves both the forgiver and the forgiven (Pattison 1989:172); it requires substitution and restitution. Whilst confession, remorse and restitution are the responsibility of the guilty, forgiveness creates an event of mutual togetherness and acceptance. The act of reconciliation thus links the guilty and the forgiver. In forgiveness, the guilty party accepts the implication of being delivered into and being dependent upon the love of the other (Louw 2016:547). The forgiver should also share the guilt, anguish and estrangement of the sinner (Pattison 1989:172) and thereby making substitution a concrete act of real reconciliation. 'To identify with the guilty person implies

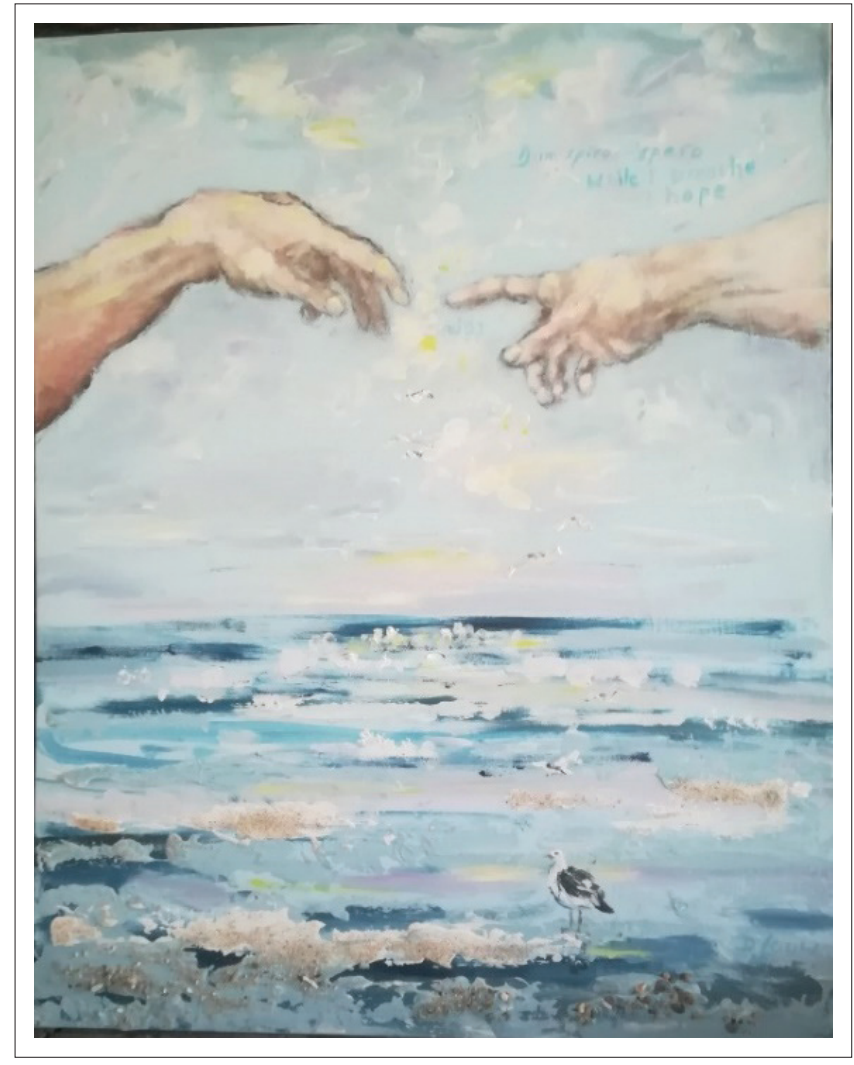

Source: Painting by, and published with permission from the author, Daniël J. Louw. FIGURE 2: Dum spiro - spero [While I breathe, I hope]. that one accepts the feeling of guilt in oneself. This may be blocked by the self-righteousness of the forgiver' (Pattison 1989:172). The refusal to forgive, gives the victim justification for retaliation; thus hampering the process of change through reconciliation (Louw 2016:547).

- Forgiveness is not instant. It is not about exonerating oneself. It is not about a 'handsome apology' (Tutu). As process category, it is embedded in the happenstances of different life events and align along the parameters of narrating. Forgiveness starts with self-forgiveness as an outcome of discovering oneself (self-insight - being the 'peacock'), and also facing the reality of being a perpetrator. The victim moves from scapegoating into selfacknowledgement with the soul reaching question: Am I perhaps also the perpetrator? This kind of self-discovery is not about intrapsychic self-analyses, but a spiritual process of becoming whole-anagnorisis as wholeness and healing.

- Anagnorisis could thus be called the most powerful image of becoming whole in a praxis of hope care. Anagnorisis is about a soulful habitus and a profound illustration of what is meant by a praxis of pastoral caregiving in theory formation for practical theology. It is a profound illustration of the metaphor: God as Host in pastoral caregiving; the victim and perpetrators creating a metaphysical space of mutual embracement beyond (the transcendent realm) the cul de sac of 'an eye for an eye'.

- Within a Christian and spiritual paradigm, forgiveness and reconciliation are interconnected and not to be separated. They are both linked to the divine intervention of a covenantal promise (the promissio-dimension); an understanding of God's being-with his people: I am who I am and will always be there present where you are. In this sense God is a journeying Exodus-God - on-his-waywith and therefore a 'Processing God'. His divine intervention with his people is in both the Old and New Testament linked to his grace, faithfulness (hêesed) and compassionate mercy (rēchèm). This can be called the foundation of all forms of a Christian reaching out to the other or others in their suffering and struggle to come to terms with the demands of life. The proof of the trustworthiness of a divine reaching out is centralised in the notion of sacrificial love - unconditional care so that both forgiveness and reconciliation are exercised within the aforementioned categories aligning them as spiritual directives in all acts of spiritual healing; the reconnection and restoration of broken relationships. Reconciliation and forgiveness are two sides of the same coin: mercy, pity and compassion. They are supplementary.

- Forgiveness points to the healing, annihilation, negation of the wrongdoing and the trespassing of the will of God as explained in and directed by the commandment of love. It is closely linked to the acknowledgement of disobedience and therefore guilt. Central therefore is the notion of sinfulness, that is, acknowledgement of the fact that life (personal and communal and collective) does not exemplify the categories of mercy and unconditional love, and therefore are missing the 'target' of our mission in life (the interplay between the missio Dei, promissio Dei and passio $\mathrm{Dei})$. Forgiveness, therefore, emanates from the centrifugal 
and centripetal point of Christian spirituality: Sacrificial love exemplified in the theologia crucis, that is, the suffering Son of God ending in a suffocating cry of radical forsakenness (divine dereliction). The core of forgiveness is a divine act; it is about vicarious suffering, substitution and exchange - in the place of the other for the other.

- Reconciliation explains the impact, result and outcome of forgiveness as a new state of mind and being. It is about reorientation of life because of confession of transgression, acknowledgement of guilt, a radical renewal (conversion) and therefore a restoration of a relationship with God that also implies a new relationship with fellow human beings. The new relationship establishes peace and a disposition (habitus) of kindness, fairness, charity and care. Its trustworthiness (truth) is revealed in acts of reconnecting, restoration and a discovery of the value of co-humanity, coexistence and humane dignity. As a result of the establishment of human dignity, both forgiveness and reconciliation are linked to moral obligations and ethics. Central therefore are expiation and retribution, because the damage must be repaid and cannot be forgotten. Forgiveness and reconciliation are therefore not attempting to forget, but modes of remembering the damage (the pain, suffering, dehumanisation) from the viewpoint of the other or others. It is at this point that the mutual interplay between the perpetrator and victim comes into play. As a result of the complexity of justice-injustice and the fallibility of human beings, the perpetrator-victim complexity is never one-sided, but a mutual networking that always needs flexibility and relativity. All the data (the so-called fact of cases of transgression and wrongdoing - empirical dimension) are embedded into intriguing transactions that should be weighed and discussed in forums (public spaces and places) of fair dialogue and trustworthy dedication to unravel the truth as embedded in life stories. Therefore, narrating the events is always in process and never fixed and instant.

- Both forgiveness and reconciliations are not immediate and instant and not about forgetfulness, but about a continuing outreach to the other because of the spiritual insight: anagnorisis as self-recognition and self-acknowledgement. The reality of this anagnorisis is demonstrated in two dispositions:

- Not to wait for the other to start with forgiveness and reconciliation, but the willingness to take the first step; the movement towards the other or others (even the enemy).

- The reaching out, stretching out to the other in gestures of embracement - being there with the other or others, talking and emphatically listening UNTIL ... This until is called by Levinas (1994) désir métafysique in which real, authentic forgiveness can take place. But the 'until' can never be forecasted; thus the reason why acts of forgiveness and reconciliation (reaching out [diakonia]; comfort [parakalein]) are always sacrificial and painful, and needs the patience of compassionate waiting and the trustworthiness of caring being-there where the other or others are. In this sense, the process of forgiving and reconciling are a never-ending story, but this 'eternal' beingthere with grace, kindness, fairness, justice, care and compassion is what hope-giving in pastoral care and diaconal reaching out are about.

The 'spiritual Marxist', Ernst Bloch (1959), within the background of his Jewish heritage, wrote a book on hope as the ontological principle of life (docta spes - Bloch 1970:318). The principle of hope and spirituality of hope are about the discovery of the true image of liberation and the establishment of trustworthy forms and modes of human freedom beyond all forms of race and class discrimination in society. The true and authentic revelation of reconciling forgiveness enfolds for Bloch in the drama of Joseph and his brothers. In the weeping of Joseph and their tears, whilst embracing one another, blinked in what Bloch paradoxically called: the darkness (mystique of human encounters) of the vivid (lived, experienced) moment of humane significance. This aha-moment is, for Bloch (1954:16), the spiritual awareness of the 'Dunkel des gelebten Augenblicks' - living life within the twilight between light (meaning) and darkness (nothingness); the not-yet of human anticipation; a kind of vision that can be called 'non-empirical' (Nicht-Empirie). The principle of hope is in essence a spiritual category or utopian spirit (Geist der Utopie) (Bloch 1964) that keeps human beings alive and going - even if daily living is pointing to the opposite direction. This is why a Christian's spirituality and praxis of hope care is about Dum spiro - spero [while I breathe, I hope]; dum vita est spes est [while there's life, there's hope]. ${ }^{14}$

The painting in Figure 2 depicts the moment of the creation of Adam (red dust) when God breathed into his nostrils the breath of life (nêfêsh) (Gn 2:7). This moment can be called the spirituality of anagnorisis - acknowledgement as soulfulness; a soulful encountering with God. There are seven seagulls flying towards the space of nêfêsh. Seven is symbol for a covenantal bonding between man and God $(4=$ the number of man; $3=$ the number for Trinity. $4+3=$ covenant; faithfulness of God). The seagull represents the life and soul of the artist.

\section{Acknowledgements}

Through this article, I want to honour the research of my colleague, Gert Breed, within the realm of practical theology and specifically, his dedication to connecting the praxis of diakonia and care to the methodology of biblical hermeneutics.

\section{Competing interests}

The author declares that they have no financial or personal relationships that may have inappropriately influenced them in writing this article.

\section{Author's contribution}

D.J.L. is the sole author of this research article.

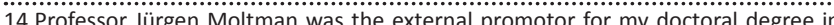
philo (2017), on the first page of my book Wholeness in Hope Ca visit to Stellen bosch (2017), on the fist page of my book Wholeness in Hope Care (Louw' 2016) he wrote: 'Dum spiro - spero', which is Latin for 'Whilst I Breathe, I Hope'. My own motto for meaningful living can be captured by the following: Dum vita est spes est [while there's life, there's hope] 


\section{Ethical considerations}

This article followed all ethical standards for research without direct contact with human or animal subjects.

\section{Funding information}

This article did not receive any grant from any funding agency in the public commercial, or not-for-profit sectors.

\section{Data availability}

The authors confirm that the data supporting the findings of this study are available within the article.

\section{Disclaimer}

The views and opinions expressed in this article are those of the author and do not necessarily reflect the official policy or position of any affiliated agency of the author.

\section{References}

Andrew, A., 2020, 'Humankind: A hopeful history by Rutger Bregman. Review - A tribute to our better nature', The Guardian, viewed 17 June 2020, from https:// www.theguardian.com/books/2020/may/12/humankind-a-hopeful-history-byrutger-bregman-review.

Bloch, E., 1954, 'Zweierlei Kant-Gedenkjahre', Deutsche Zeitschrift für Philophie 2(1), 5-17. https://doi.org/10.1524/dzph.1954.2.1.5

Bloch, E., 1959, Das Prinzip Hoffnung, Suhrkamp Verlag, Frankfurt am Main.

Bloch, E, 1962, Erbschaft dieser Zeit, Band 4, Suhrkamp Verlag, Frankfurt am Main.

Bloch, E., 1964, Geist der Utopie, Suhrkamp Verlag, Frankfurt am Main.

Bloch, E., 1968, Atheismus im Christentum. Zur Religion des Exodus und des Reiches, Band 14, Suhrkamp Verlag, Frankfurt am Main

Bloch, E., 1969, Philosophische Aufsätze, Band 10, Suhrkamp Verlag, Frankfurt am Main.

Bloch, E., 1970, Tübinger Einleitung in die Philosophie, Band 13, Suhrkamp Verlag, Frankfurt am Main.

Blunk, J., 1975, 'Anaginōskō', in C. Brown (ed.), Dictionary of New Testament Theology, vol. I, pp. 245-246, The Paternoster Press, Exeter.

Constitution of the Republic of South Africa 1996 (Act 108), p. 1, viewed 17 June 2020 from https://www.justice.gov.za/legislation/constitution/SAConstitution-webeng.pdf.

Du Preez, M., 2013, A rumour of spring. South Africa after 20 years democracy, Zebra Press, Cape Town.

Esterhuyse, W., 2000, 'Truth as a trigger for transformation: From apartheid injustice to transformational justice', in C. Villa-Vicencio \& W. Verwoerd (eds.) Looking back. Reaching forward. Reflections on the Truth and Reconciliation Commission in South Africa, pp. 144-154, University of Cape Town Press, Cape Town.

Fitchett, G. \& Grossoehme, D., 2012, 'Health care chaplaincy as a research-informed profession', in B. Stephan \& B. Roberts (eds.), A practical Clergy and Chaplain's handbook, pp. 387-406, Skylight Paths, Woodstock, GA.
Girard, R., 1986, The scapegoat, Johns Hopkins University Press, Baltimore, MD.

Goldstone, R., 2000, 'Foreword', in C. Villa-Vicencio \& W. Verwoerd (eds.), Looking back. Reaching forward. Reflections on the Truth and Reconciliation Commission in South Africa, pp. viii-xiii, University of Cape Town Press, Cape Town.

Graber, F. \& Müller, D., 1978, 'Heal (therapeuo)', in C. Brown (ed.), Dictionary of New Testament Theology, vols. 2 and 3, pp. 164-165, Paternoster Press, Exeter.

Hernandez, W., 2012, Henri Nouwen and spiritual polarities: A life of tension, Paulist Press, New York, NY.

Levinas, E.M., 1978, Het menselijk gelaat, Selection and introduction: Ad Peperzak, transl. O. de Nobel \& A. Peperzak, Ambo, Baarn.

Levinas, E.M.,1990, God en de filosofie, transl., intro., notes Th. de Boer, Meinema, 's-Gravenhage.

Levinas, E.M., 1994, Les Imprévues de l'Histoire, Préface de Pierre Hayat, Fata Morgana, Paris.

Louw, D.J., 2016, Wholeness in Hope Care: On nurturing the beauty of the human soul in spiritual healing, Lit Verlag, Wien.

Malema, J., 2020, 'South Africa: Lockdown - Stay away, rather die with your boots on says Malema', All Africa News24Wire, 29 May, viewed 16 July 2020, from https:// allafrica.com/stories/202005290220.html.

Mamphela, R., 2012, Conversations with my sons and daughters, Penguin Books, Johannesburg

Mann, T., 1970, Joseph and his brothers, Secker \& Warburg, London.

Meiring, P., 1999, Kroniek van die Waarheidskommissie: Op reis deur die verlede en die hede en na die toekoms van Suid-Afrika, Carpe Diem Boeke, Vanderbijlpark.

Mgxashe, M., 2000, 'Reconciliation: A call to action', in C. Villa-Vicencio \& W. Verwoerd (eds.), Looking back. Reaching forward. Reflections on the Truth and Reconciliation Commission in South Africa, pp. 210-218, University of Cape Town Press, Cape Town.

Nouwen, H.J.M., 1979, The wounded healer: Ministry in Contemporary Society, Doubleday, Garden City, NY.

Nouwen, H.J.M., 1998, Reaching out, Fount Paperbacks, London.

Pattison, E.M., 1989, 'Punitive and reconciliation models of forgiveness', in L. Aden \& D.G. Benner (eds.), Counselling and the human predicament. A study in sin, guilt and forgiveness, pp. 172-193, Baker Book House, Grand Rapids, MI.

Ramaphosa, C., 2019, State on the nation address, viewed 27 June 2019, from https:// mg.co.za/article/2019-06-20-read-it-in-full-ramaphosas-state-of-the-nationaddress.

Serfontein, J.H.P., 1979, Brotherhood of power. An exposé of the secret Afrikaner Broederbond, Rex Collins Limited, London.

Slye, R., 2000, 'Justice and amnesty', in C. Villa-Vicencio \& W. Verwoerd (eds.), Looking back. Reaching forward: Reflections on the Truth and Reconciliation Commission in South Africa, pp. 174-183, University of Cape Town Press, Cape Town.

Van Rhijn, A. \& Meulink-Korf, H., 2019, Appealing spaces. The interplay between justice and relational healing in caregiving. The ethics of humane networking, BM Biblecor, Wellington.

Verwoerd, W., 2000, 'Towards the recognition of our past injustices', in C. VillaVicencio \& W. Verwoerd (eds.), Looking back. Reaching forward: Reflections on the Truth and Reconciliation Commission in South Africa, pp. 155-165, University of Cape Town Press, Cape Town.

Villa-Vicencio, C., 2000, 'Getting on with life: A move towards reconciliation', in C. Villa-Vicencio \& W. Verwoerd (eds.) Looking back. Reaching forward: Reflections on the Truth and Reconciliation Commission in South Africa, Reflections on the Truth and Reconciliation Commissio
pp. 199-209, University of Cape Town Press, Cape Town.

Villa-Vicencio, C. \& Verwoerd, W., 2000, 'Introduction', in C. Villa-Vicencio \& W. Verwoerd (eds.), Looking back. Reaching forward: Reflections on the Truth and Reconciliation Commission in South Africa, pp. xiv-xxi, University of Cape Town Press, Cape Town.

Vosloo, R., 2006, Engele as gaste: Oor gasvryheid teenoor die ander, Lux Verbi, Wellington.

Yazir, H., 2000, 'Where healing begins', in C. Villa-Vicencio \& W. Verwoerd (eds.), Looking back. Reaching forward: Reflections on the Truth and Reconciliation Commission in South Africa, pp. 166-173, University of Cape Town Press, Cape Town. 